удк 332.132

\title{
СИСТЕМА РЕГІОНАЛЬНИХ ЧИННИКІВ У ПРОЦЕДУРІ ПОШУКУ ОПТИМАЛЬНОГО МІСЦЯ ІНВЕСТИЦИИНО-ПРОСТОРОВОГО ОРІЕНУВАННЯ БІЗНЕСУ КРІЗЬ ПРИЗМУ БІОЕКОНОМІКИ
}

\author{
SYSTEM OF REGIONAL FACTORS \\ IN THE PROCEDURE OF SEARCHING THE OPTIMAL \\ PLACE FOR INVESTMENT-SPATIAL ORIENTATION \\ OF BUSINESS THROUGH PRISMON PRISM
}

\author{
Качала Тамара Миколаївна \\ доктор економічних наук, професор, \\ Таврійський національний університет імені В.І. Вернадського \\ ORCID: https://orcid.org/0000-0002-6885-792X \\ Карлова Олена Анатоліївна \\ доктор економічних наук, профресор, \\ Українська інженерно-педагогічна академія \\ ORCID: https://orcid.org/0000-0002-5506-4154 \\ Лучин Олег Миколайович \\ генеральний директор, \\ ПП «Владі Транс» \\ ORCID: https://orcid.org/0000-0002-5643-8031 \\ Kachala Tamara \\ V.I. Vernadsky Taurida National University \\ Karlova Olena \\ Ukrainian Academy of Engineering and Pedagogy \\ Luchin Oleh \\ PE "Vladi Trans"
}

\begin{abstract}
Робота направлена на розв'язок проблеми інвестиційно-просторового орієнтування бізнесу за допомогою використання системи регіональних чинників в алгоритмі пошуку оптимального місця інвестиційно-просторового орієнтування. Визначено роль чинників в пошуку оптимального місця інвестиційно-просторового орієнтування бізнесу. Критично проаналізовані існуючі підходи розв'язку проблеми просторового орієнтування бізнесу. Доведено доцільність доповнення відомих чинників просторового орієнтування бізнесу чинниками регіонального значення, тобто чинниками, які властиві для кожного досліджуваного регіону в тій чи іншій мірі. Обґрунтовано, що при дослідженні певний геограсрічно-економічний регіон в напрямі пошуку оптимального місця просторового орієнтування бізнесу застосовуючи пропоновані регіональні чинники суттєво зросте ймовірність врахування всіх можливих місць в системі пошуку оптимального місця просторового орієнтування бізнесу. Досліджено і проаналізовано регіональне оточення підприємства.

Ключові слова: просторове орієнтування бізнесу, чинники розміщення підприємств, біоекономіка, регіональне оточення бізнесу, регіональна економіка, розвиток продуктивних сил.
\end{abstract}

Работа направлена на решение проблемы инвестиционно-пространственной ориентировки бизнеса посредством использования системы региональных фракторов в алгоритме поиска оптимального инвестиционно-пространственной ориентировки. Определена роль факторов в поиске оптимального места инвестиционного ориентирования бизнеса. Критически проанализированы существующие подходы решения проблемы пространственного ориентирования бизнеса. Доказана целесообразность дополнения известных фракторов 
пространственной ориентировки бизнеса фракторами регионального значения, то есть фракторами, которые характерны для каждого исследуемого региона в той или иной степени. Обосновано, что исследуя определенный геограсрически-экономический регион в направлении поиска оптимального места пространственного ориентирования бизнеса применяя предлагаемые региональные фракторы существенно возрастет вероятность учета всех возможных мест в системе поиска оптимального места пространственного ориентирования бизнеса. Исследовано и проанализировано региональное окружения предприятия.

Ключевые слова: пространственное ориентирование бизнеса, фракторы размещения предприятий, биоэкономика, региональное окружение бизнеса, региональная экономика, развитие производительных сил.

It has been proven that the solution to the problem of investment-spatial orientation of business comes down to finding the optimal place for business location. The key point is to reduce the number of possible places to place the business in the optimal search algorithm. Many aggregate approaches are used to address this issue, one of which is the formation of factors of spatial orientation of the business. Existing approaches to solving the problem of spatial orientation of business are critically analyzed. The expediency of supplementing the known factors of spatial orientation of business with factors of regional significance, ie factors that are specific to each studied region to one degree or another, is proved. Among them: the regional factor of uneven consumption of similar products and services; local legislation (restrictions, taxes, support of authorities, etc.); infrastructural development of the region and the climate of the region. It is determined that the emergence of new or relocation of existing enterprises or their branches contributes to the development of specific advantages of the new location or eliminates the disadvantages of the former location for certain consumer functions, such as proximity of new production branches to customers, relocation of labor-intensive shops to lower wages. or the use of government subsidies in special areas and areas of the country. It is substantiated that researching a certain geographical and economic region in the direction of finding the optimal place of spatial orientation of business using the proposed regional factors will significantly increase the probability of taking into account all possible places in the system of finding the optimal place of spatial orientation of business. The regional environment of the enterprise is researched and analyzed, namely: consumers (existing, potential); state control bodies (inspections, commissions, etc.); financial and credit institutions (banks, insurance, etc.); communities (public organizations, trade unions, etc.); regional legislation; individuals and legal entities that show a certain interest in the enterprise (families of employees, shareholders, parent companies; competitors (bona fide, aggressive, etc.).

Keywords: spatial orientation of business, factors of enterprise location, regional business environment, bioeconomy, regional economy, development of productive forces.

Постановка проблеми. Існування територіальної відмінності витрат виробництва і сучасного розвитку транспортних технологій який дозволив перевозити продукти виробництва на велику відстань породило проблему просторового орієнтування бізнесу. Розв'язок даної проблеми зводиться до пошуку оптимального місця просторового орієнтування бізнесу. Ключовий момент при цьому полягає в скороченні кількості можливих місць для розміщення бізнесу в алгоритмі пошуку оптимального. Для вирішення цього питання застосовуються багато сукупних підходів, одним з яких $є$ формування чинників просторового орієнтування бізнесу.

Аналіз останніх досліджень і публікацій. Значення проблеми вибору місця розташування залежить від того, на якому рівні вона вирішується: міжнародний вибір - у якій країні розміщується підприємство; регіональний вибір -у якому регіоні країни підприємство буде знаходитись; локальний вибір - у якому місці регіону підприємство розмішується; внутрішньо локальний вибір - у якому місці на даній території воно розміщується; просторовий вибір як розміщене підприємство у просторі на даній території, площадці, споруді і т. д.
Так, підхід С. Єрьоміна в [1, с. 143-157] характеризується на таких методах обґрунтування розміщення підприємств: системний аналіз; балансовий метод; техніко-економічні розрахунки; економіко-статистичні та економіко-математичні методи; картограсрічний метод; балансові та оптимізаційні моделі.

Дещо перекликаються 3 С. Єрьоміним пропоновані методи С. Доргунцова, проте мають і суттєву відмінність. Так, С. Доргунцов в [2, с. 97-102] до числа специфічних методів науки про розміщення продуктивних сил i територіальної організації національного господарства відносить як традиційні, так і нові. До основних 3 них відносяться: вивчення конкретного підприємства і аналіз його господарської діяльності, виробничого потенціалу, технологічних особливостей, складності виробничого процесу, зв'язків по поставках сировини і реалізації готової продукції, енергетичної і кадрової забезпеченості, можливостей збільшення потужностей, перспективності розвитку тощо; вивчення елементарної системи виробництва, до складу якої входить підприємство; вивчення галузевого розміщення продуктивних сил і галузевої структури господарства міста, району, області, країни. 
Аналіз розв'язання задач пошуку оптимального місця розміщення об'єктів (підприємств) методами математичного моделювання представлений А. Катренком і Т. Антоняком в [3-5].

В науковій літературі можна зустріти задачі розміщення об'єктів на грасрі, які є модисрікаціями наведених вище базових задач. Зокрема, так звана задача розміщення з додатковими умовами. Такими умовами може бути розташування об'єктів на площині із забороненими зонами або розташування нових об'єктів у вузлах графра в яких вже містяться фріксовані об'єкти [6].

Заслуговує також на увагу механізм пошуку оптимального місця розміщення підприємства представлений в [7]. Тут автор розглядає багатоетапну задачу розміщення виробництва.

Безперечно кожен з проаналізованих нами підходів просторового орієнтування бізнесу має шанс на практичне використання навіть в умовах видачі неповних чи не комплексних для бізнесу результатів з пошуку оптимального місця розміщення. Проте, не вирішує проблему в цілому.

Формулювання цілей статті. Розв'язок проблеми інвестиційно-просторового орієнтування бізнесу за допомогою використання системи регіональних чинників в алгоритмі пошуку оптимального місця інвестиційно-просторового орієнтування бізнесу.

Виклад основного матеріалу дослідження. Досліджуючи повноту охоплення всіх можливих місць просторового орієнтування бізнесу відомими чинниками просторового орієнтування нами доведено доцільність їх доповнення чинниками регіонального значення. Тобто чинниками, які на наше переконання властиві для кожного досліджуваного регіону в тій чи іншій мірі. Таким чином досліджуючи певний географрічно-економічний регіон в напрямі пошуку оптимального місця просторового орієнтування бізнесу суттєво зросте ймовірність врахування всіх можливих місць в системі пошуку оптимального місця просторового орієнтування бізнесу. Обґрунтуємо економічну доцільність кожного з представлених регіональних чинників.

Регіональний чинник нерівномірності споживання аналогічних видів продукції та послуг. Не потребує обґрунтування поняття, що певний продукт може споживатися 3 досить суттєвою різницею в різних регіонах. Так, $є$ доведено, що в засушливих регіонах споживається більше питної води, ніж наприклад, в карпатському регіоні. Зрозуміло, що споживання автомобільного палива є біль- шим там, де більша концентрація автотранспорту, тощо.

В маркетинговій практиці $є$ багато методів, щодо аналізу нерівномірності споживання: коефріцієнт локалізації Лоренца і індекс локалізації; закон Парето; правило важкої половини; індекс Лінда та ін.

Другий регіональний чинник це - місцеве законодавство (обмеження, податки, підтримка органів влади та ін.).

Третій регіональний чинник - інфраструктурний розвиток регіону та клімат регіону. Справа тут в тому, щоб узгодити які вимоги ставляться до розміщення конкретного виду бізнесу і реально існуючі або прогнозовані умови його розташування. Адже, можливий такий варіант, коли з впливом часу регіональні умови для ведення бізнесу змінилися. Так, м. Львів 3 колишнього науково-індустріального міста перетворилося в туристичне місто. Майже всі заводи збудовані в радянський час «зникли», а нові, які споруджуються в.т.ч. завдяки іноземним інвестиціям розміщуються навколо Львова в радіусі до 100 км.

Серед причин зміни місця розташування фрірми (підприємства) виокремлюють недоліки існуючого та (або) переваги нового місць дислокації. При цьому розглядають нові ризики, такі як ризик невідповідності реальних переваг нового місця розташування прогнозованим та ризик руйнації усталених територіальних зв'язків.

Поява нових або переміщення діючих підприємств чи їх фрілій спрямоване на освоєння специярічних переваг нового місця розташування або усунення недоліків колишнього розміщення для певних споживчих фрункцій, наприклад, близькість нових виробничих фрілій підприємства до покупців, перебазування трудомістких цехів в місця з більш низькою оплатою праці або використання державних субсидій в особливих зонах і районах країни.

Таким чином можна ілюстративно представити вплив регіональних чинників на розміщення підприємства (рис. 1).

Якщо більш ширше глянути на ближнє i дальнє оточення, то їх в сукупності можна охарактеризувати так (рис. 2):

Для повного розуміння картини розглянемо детальніше це оточення. Особливої уваги для споживачів приділяти не варто відзначимо тільки те, що це особи, що користуються послугами компанії купуючи у неї самостійно або через інших осіб її продукцію. Для потенційних клієнтів компанії зазвичай фрормують рекламні матеріали. Основними параметрами 


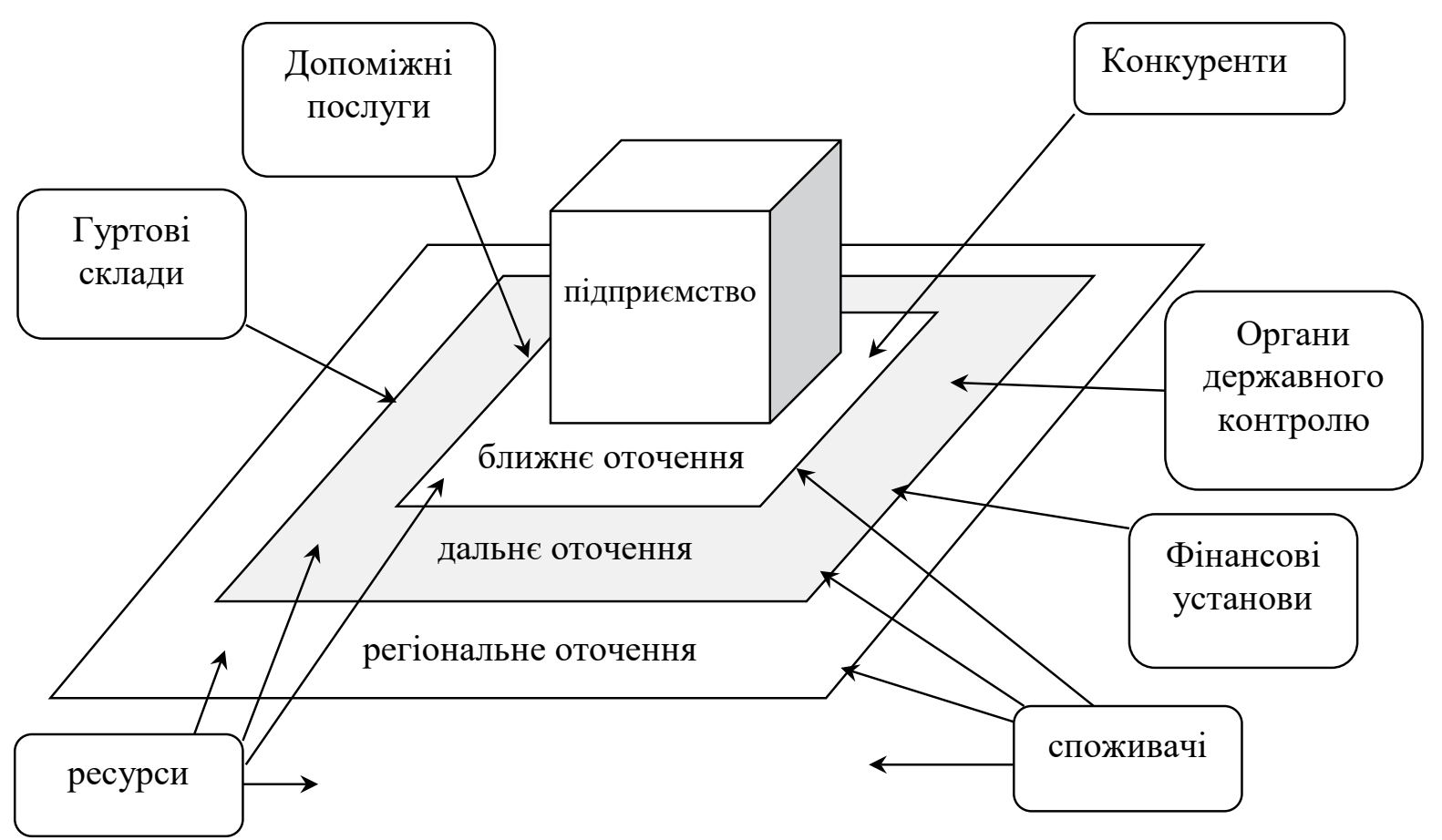

Рис. 1. Регіональне оточення підприємства

Джерело: [1]

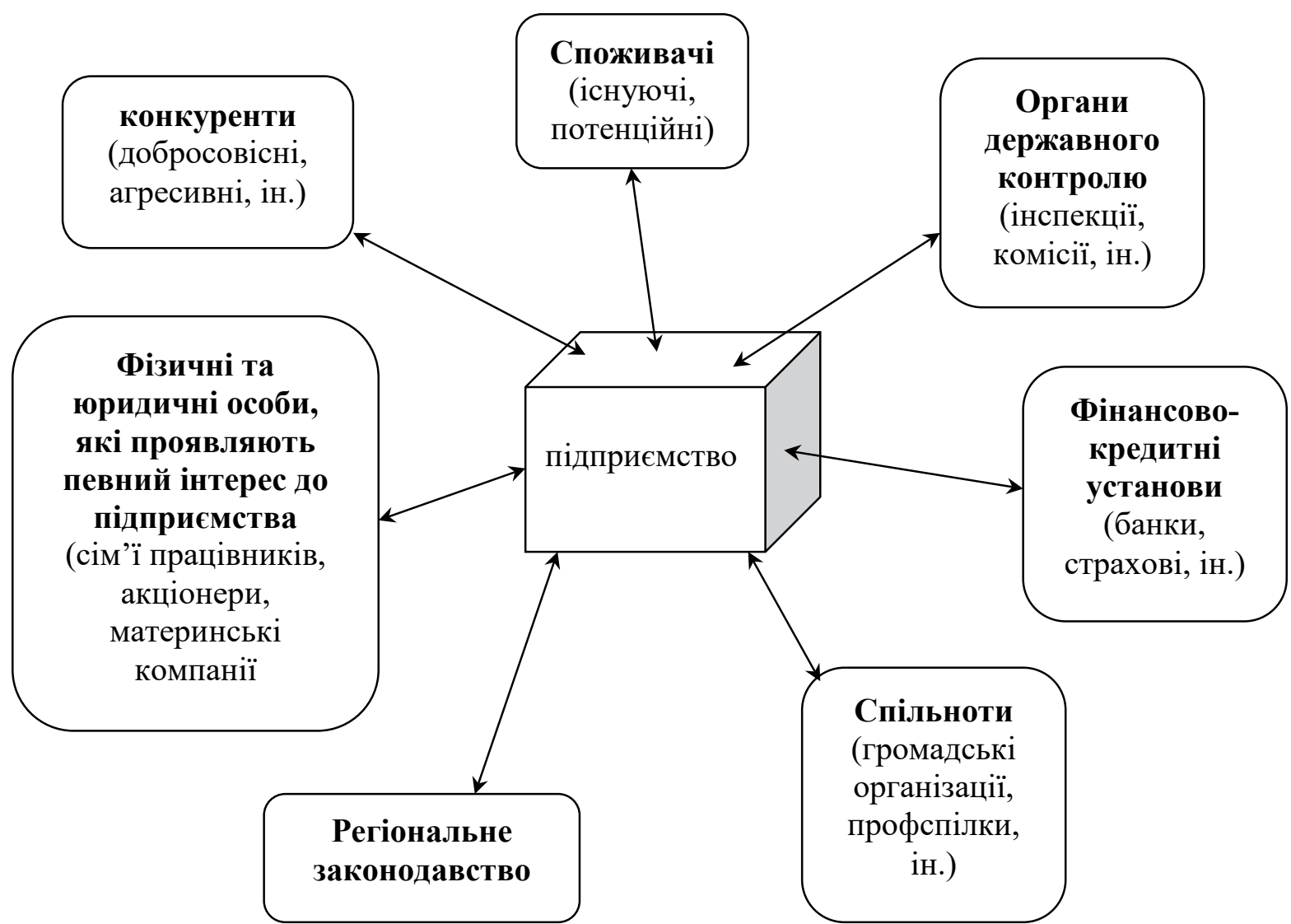

Рис. 2. Середньо-віддалене оточення підприємства Джерело: [1] 
для даного елементу є: обсяг незадоволених населенням потреб та інтересів; рівень платоспроможності населення; стан попиту і пропозиції; прайс-листи, знижки та пропозиції...

Органи державного контролю здійснюють податкові, адміністративні, санітарні, пенсійні, медичні, соціальні та інші інспекції. Параметри цього елементу складаються 3: рівня правової та інорормаційної підтримки; рівня адміністративної підтримки.

Фінансово-кредитні установи - це організації, які беруть участь безпосередньо у фрінансовому житті компанії. Вони виконують роль розрахунково-касових, іпотечних, кредитних та інших операцій. Параметри цього елементу складаються 3: швидкості і якості обслуговування; рівня надійності; банківських резервів; обсягу послуг.

Фізичні та юридичні особи, які проявляють певний інтерес до підприємства - це особи, зацікавлені в економічному зростанні компанії виходячи зі своїх особистих інтересів. До них відносяться члени сімей працівників компанії, утримувачі цінних паперів компанії, пенсіонери, про яких додатково піклується компанія, материнські і інші компанії. Основні параметри цього елементу складаються 3: рівня втручання в діяльність підприємства певних груп населення; ступеню розвиненості фрондових ринків цінних паперів; характеру допомоги соціально незахищеному прошарку населення; загального рівня економічного добробуту населення.

Конкуренти - обов'язковий елемент ринкової економіки. Основними параметрами цього елементу є: рівень еластичності продукції що випускається компанією; обсяг привілей якими володіють конкуренти; характер поточного та прогнозованого попиту; співвідношення вітчизняних і закордонних конкуруючих компаній.

Спільноти фрормують у свідомості населення відношення до підприємства та його продукції. Ключовими параметрами цього елементу слід виділити: головні цілі та завдання профрспілкової організації; відношення громадськості до якості виготовленої підприємством продукції; тощо.

Регіональне законодавство як складова оточення характеризується такими основними параметрами: частотою змін; рівнем доступності для користувачів; ступенем охоплення правового простору; об'ємом контролю за виконанням.

На цьому етапі доцільно розібратися і 3 регіональним та поза регіональним оточенням. До нього відносяться ті складові, які знаходяться поза сферою безпосереднього впливу: системи цінностей і пріоритетів в суспільстві; звичаї місцевого та міжнародного ділового співробітництва; політичні обставини в державі та на світовій арені; економічні обставини в галузі, країні та світі; соціальні та екологічні, біоекономічні передумови; імовірність стихійного лиха, тощо.

Системи цінностей і пріоритетів в суспільстві можуть включати матеріальні, суспільнополітичні та духовні цінності. Адже для окремих суспільств існує своє уявлення про добро, справедливість, свободу, віру, тощо. Такі суспільні формування можуть фрормувати як позитивну систему цінностей, так і негативну. Разом з тим притаманні і загальнолюдські цінності: норми моральності, прогрес, культурна спадщина, соціальна відповідальність. Керуючий підприємством мусить орієнтуватися в існуючих соціальних цінностях і фрормувати спільну з суспільними цінностями політику підприємницької діяльності.

Звичаї місцевого та міжнародного ділового співробітництва складаються з публічно прийнятих норм ділових відносин між учасниками будь-яких угод, які не підпадають під регулювання законодавчими актами. Тут слід відзначити: масштаб звичаїв ділового співробітництва; вагомість в суспільстві звичаїв ділового співробітництва; статистику дотримання звичаїв ділового співробітництва у сорері діяльності підприємства; існування відповідальності за порушення таких звичаїв.

Політичні обставини в державі та на світовій арені характеризуються: діяльністю органів державної влади та державного управління, що характеризує суспільний лад і економічну структуру суспільства; відкритістю політичних партій, громадських об'єднань і соціальних угрупувань. Складовим для фрормування цього елементу є: рівень довіри населення до влади; відсоток залучення громадськості до проектування і реалізації головних програм державної влади і місцевого самоврядування; ступінь інтеграції країни зі світовим співтовариством.

Економічні обставини в галузі, країні та світі визначаються організуванням, структурою і станом господарської діяльності галузі, країни або світового регіону. Основні параметри складаються: з рівня стабільності економічних обставин; 3 тривалості циклу економічних коливань; з рівня інфрляції; з ступеню привабливості для інвесторів.

Соціальні, екологічні, біоекономічні передумови характеризуються моральною відповідальністю підприємства і окремих осіб за 
негативні наслідки реалізованих управлінських рішень, тобто за шкоду, заподіяну людям або природі. Основні екологічні, соціальні та економічні проблеми сьогодення породжують нові виклики подолання яких передбачає, що сучасні підприємства мають докорінно змінити свій підхід до виробництва, споживання, переробки, зберігання, переробки та утилізації біологічних ресурсів. Як нова економічна парадигма на передній план постає біоекономіка головна місія якої мінімізація несприятливих впливів економічної діяльності на навколишнє середовище, яка дозволить досягти важливих цілей сталого розвитку. Перехід на біоекономіку передбачає заміну викопних матеріалів у широкому спектрі галузей промисловості поновлюваними джерелами вуглецю, а також підвищення ресурсоесрективності та збереження значень ресурсів у матеріальних колах [8]. Поряд 3 екологічними перевагами, пов'язаними з такими інноваціями, біоекономіка відкриває цілу низку економічних можливостей, зокрема формування нового бізнесу в сільській місцевості, зменшення залежності від імпорту та посилення секторів, що ґрунтуються на знаннях [9-10].

Важливими параметрами соціальних, екологічних та біоекономічні передумов $€$ : широта відповідальності, обсяг фрункцій виробництва і управління, за якими підприємство чи керівник бере на себе соціальну або екологічну відповідальність; часовий інтервал відповідальності, який характеризується як період стійкої уваги і конкретних дій щодо дотримання моральних норм у всьому діапазоні заявлених фрункцій виробництва і управління підприємством. Часовий інтервал може бути безстроковим і на певний період. Наприклад, на період виконання певного завдання; заохочуваність персоналу в реалізацію соціальних та екологічних цілей підприємства, що може бути досягнуто двома шляхами: 1) за рахунок орормування окремих професійних колективів у складі підприємства для їх досягнення; 2) за рахунок участі всього колективу компанії на громадських засадах у позаробочий час для їх досягнення.

Інституціональні структури складаються 3 обслуговуючих компанію організацій, наприклад, страхові, срінансові організації, фронди, біржі, посередницькі організації, суди, охоронні фрірми, тощо. До основних параметрів інституційних структур відносяться: ступінь задоволення потреб компаній в додаткових послугах; доступність послуг для користувачів.

Імовірність стихійного лиха включає як фрорс-мажорні, так і характерні (часто повторювані) природні аномалії: землетруси, зливи й урагани, повені та ін. До основних параметрів стихійного лиха відносимо: їх характерний перелік; частоту повторень; характер і рівень збитку, ними викликаного; вартість захисних заходів щодо зменшення можливого збитку.

Висновки 3 даного дослідження і перспективи подальших досліджень у даному напрямку. Отже, можна обґрунтовано стверджувати, що при пошуку оптимального місця просторового орієнтування бізнесу повні вихідні дані отримаємо тоді, коли окрім врахування відомих «глобальних» чинників просторового орієнтування бізнесу будуть враховані пропоновані нами регіональні чинники.

Подальші наукові дослідження будуть спрямовані у напрямі розширення представлених чинників для врахування ними специоріки виробничих процесів у підприємницькій діяльності, які стосуються застосуванням у виробництві принципів біоекономіки чи циклічної економіки.

СПИСОК ВИКОРИСТАНИХ ДЖЕРЕЛ:

1. Єрьомін С. Розміщення продуктивних сил. Київ : Знання, 2003. 350 с.

2. Розміщення продуктивних сил України : Навч.-метод. посібник для самост. вивч. дисц. / [С.І. Дорогунцов, Ю.І. Пітюренко, Я.Б. Олійник та ін.]. Київ : КНЕУ, 2000. 364 с.

3. Катренко А.В., Антоняк В.І. Розв'язання задач оптимального розміщення об'єктів методом імітаційного моделювання. Вісник НУ «ЛП». Серія : Інфрормаційні системи та мережі : зб. наук. пр. 2011. № 715. С. 150-162.

4. Харари Ф. Теория графов. Москва : Мир, 1973. 301 с.

5. Кристофидес Н. Теория графов. Алгоритмический поход. Москва : Мир, 1978. 432 с.

6. Забудский Г.Г. Алгоритм решения минимаксной задачи размещения объекта на плоскости с запрещенными зонами. Автоматика и телемеханика. 2004. № 2. С. 93-100.

7. Станіна О.Д. Перспективи використання синтезу генетичного алгоритму та методу оптимального розбиття множин в задачах розміщення-розподілу. «Системные технологии». Региональный межвузовский сборник научных трудов. 2016. № 2. С. 116-122.

8. Giampietro M. On the circular bioeconomy and decoupling: implications for sustainable growth Ecol. Econ., 162 (2019), pp. 143-156. 
9. Wohlgemuth A.R., Twardowski T. Preface to the special issue bioeconomy N. Biotech., 40 (2018), pp. 1-4.

10. Brunori G. Biomass, biovalue and sustainability: some thoughts on the definition of the bioeconomy EuroChoices, 12(1) (2013), pp. 48-52.

\section{REFERENCES:}

1. Yer'omin S. (2003) Rozmishchennya produktyvnykh syl [Placement of productive forces]. Kyiv: Znannya, 350 p. (in Ukrainian)

2. Rozmishchennya produktyvnykh syl Ukrayiny (2000): Navch.-metod. posibnyk dlya samost. vyvch. dysts. [Location of productive forces of Ukraine: Teaching method. manual for self. studied dist.] / [S.I. Dorohuntsov, Yu.I. Pityurenko, Ya.B. Oliynyk ta in.]. Kyiv: KNEU, 364 p. (in Ukrainian)

3. Katrenko A.V. (2011) Rozvyazannya zadach optymalnoho rozmishchennya obyektiv metodom imitatsiynoho modelyuvannya [Solving problems of optimal placement of objects by the method of simulation modeling]. Visnyk NU "LP". Seriya: Informatsiyni systemy ta merezhi: zb. nauk. pr., no. 715, pp. 150-162. (in Ukrainian)

4. Kharary F. (1973) Teoryya hrafov [Theory of graphs]. Moscow: Myr, 301 p. (in Ukrainian)

5. Krystofydes N. (1978) Teoryya hrafov. Alhorytmycheskyy pokhod [Graph theory. Algorithmic campaign]. Moscow: Myr, 432 p. (in Ukrainian)

6. Zabudskyy H.H. (2004) Alhorytm reshenyya mynymaksnoy zadachy razmeshchenyya obekta na ploskosty s zapreshchennymy zonamy [Algorithm for solving the minimax problem of object placement on a plane with forbidden zones]. Avtomatyka y telemekhanyka, no. 2, pp. 93-100. (in Ukrainian)

7. Stanina O.D. (2016) Perspektyvy vykorystannya syntezu henetychnoho alhorytmu ta metodu optymalnoho rozbyttya mnozhyn $v$ zadachakh rozmishchennya-rozpodilu [Prospects for the use of the synthesis of a genetic algorithm and the method of optimal partitioning of sets in placement-distribution problems]. «Systemnye tekhnolohyy». Rehyonal'nyy mezhvuzovskyy sbornyk nauchnykh trudov, no. 2, pp. 116-122. (in Ukrainian)

8. Giampietro M. (2019) On the circular bioeconomy and decoupling: implications for sustainable growth Ecol. Econ., 162, pp. 143-156.

9. Wohlgemuth A.R., Twardowski T. (2018) Preface to the special issue bioeconomy N. Biotech., 40, pp. 1-4.

10. Brunori G. (2013) Biomass, biovalue and sustainability: some thoughts on the definition of the bioeconomy EuroChoices, 12(1), pp. 48-52. 